\section{Effect of Dikegulac on Flowering and Growth of Bougainvillea 'Rainbow Gold'}

\author{
J.G. Norcini ${ }^{1}$ \\ Institute of Food and Agricultural Sciences, Agricultural Research and \\ Education Center, University of Florida, Monticello, FL 32344
}

\section{J.M. McDowell ${ }^{1}$ \\ Division of Agricultural Sciences, Florida Agricultural \& Mechanical University, Tallahassee, FL 32307}

\section{J.H. Aldrich ${ }^{2}$ \\ Institute of Food and Agricultural Sciences, Agricultural Research and Education Center, University of Florida, Monticello, FL 32344}

Additional index words. dikegulac-sodium, growth regulator

Abstract. The use of dikegulac in production of hanging baskets (4.5-liter capacity) of Bougainvillea 'Rainbow Gold' was investigated under decreasing daylengths and high temperatures. Liners treated with a single application of $1200 \mathrm{ppm}$ dikegulac 4 weeks after transplanting and pruning (WATP) resulted in the only marketable hanging baskets 9 WATP. Application of 1200 ppm dikegulac 4 WATP enhanced flowering and aesthetic quality compared with plants that had only been pruned. Bract size did not appear to be reduced. Plant width tended to increase as time of application was delayed. Dikegulac had no effect on height or branching. Chemical name used: sodium salt of 2,3:4,6-bis-O-(1-methylethylidene)-a-L-xylo-2-hexulofuranosonic acid (dikegulac-sodium).

Production of hanging baskets of bougainvillea can be profitable considering the relatively short production time (rooted liner to finished plant) and premium retail prices they often command. However, increases in profitability and production could be realized if flowering and vegetative growth were more easily controlled. Considerable labor is required during production of many bougainvillea cultivars, including 'Rainbow Gold' and 'Barbara Karst', because they grow vigorously. Flowering of bougainvillea is promoted under short days, although high light intensity and moderate temperatures can also enhance flowering (Allard, 1935; Hackett and Sachs, 1966, 1967; Joiner et al., 1962).

The use of plant growth regulators (PGR) to control growth and flowering has met with limited success. Chlormequat and ancymidol caused 'Raspberry Ice' and 'San Diego Red' bougainvillea to flower 2 weeks earlier than untreated plants under short days, although neither PGR reduced height or increased shoot count (Dierking and Sanderson, 1985). Chlormequat and daminozide reduced vegetative growth of 'San Diego Red' under short and long days but only promoted flowering

Received for publication 14 Feb. 1991. Accepted for publication 6 Aug. 1991. This is Florida Ag riculture Experiment Station Journal Series no. R01364. The cost of publishing this paper was defrayed in part by the payment of page charges. Under postal regulations, this paper therefore must be hereby marked advertisement solely to indicate this fact.

'Assistant Professor.

${ }^{2}$ Senior Biological Scientist. 1990. Data were recorded 3 Oct. 1990.

${ }^{2}$ Mean no. inflorescences per flowering branch. observers. not enhance flowering of 'Raspberry Ice' bougainillea (G. Cobb, personal communication). In late Aug. 1989, I (J.G.N.) observed at a nursery in Central Florida that hanging baskets of 'Barbara Karst' bougainvillea treated with $1600 \mathrm{ppm}$ dikegulac 2 to 3 weeks earlier were flowering much more profusely than nontreated plants. The plants were near marketable size and had few to no visible inflorescences when treated, although flower buds may have already been initiated. While the bract size of the dikegulac-treated bougainvillea appeared to be reduced $25 \%$ to $50 \%$, the overall flowering impact was superior to untreated plants, which had only a few normal size inflorescences.

The purpose of this study was to determine the effect of dikegulac on growth and flowering of 'Rainbow Gold' bougainvillea under decreasing daylengths and high temperatures.

Rooted liners of Bougainvillea 'Rainbow Gold' 10 to $15 \mathrm{~cm}$ tall and growing in 0.35 liter $(11.4 . \mathrm{cm})$ pots (three liners per pot) were obtained from Hatten's Nursery, Inc. (Mobile, Ala.). One such pot was transplanted into each of thirty 4.5 -liter $(25.4-\mathrm{cm}$ diameter) baskets on 1 Aug. 1990 and placed in a research station greenhouse. The potting medium was composed of equal parts (by volume) of coarse perlite and Pro-Mix BX (sphagnum peat with equal parts of vermiculite and perlite, some major and minor elements, and a wetting agent; Premier Brands, New Rochelle, N.Y.). Plants were top-dressed with $19 \mathrm{~g}$ Osmocote $17 \mathrm{~N}-2.64 \mathrm{P}-8.3 \mathrm{~K}+$ minor elements (1.5Ca-1.0Mg-4.0S-0.02B$0.05 \mathrm{Cu}-0.4 \mathrm{Fe}-0.1 \mathrm{Mn}-0.001 \mathrm{Mo}-0.05 \mathrm{Zn}$ ) and treated with a soil drench of $37 \mathrm{ppm}$ metalaxyl $(156 \mu$ l Subdue 2E [Ciba-Geigy; Greensboro, N.C.] per liter water). On 6 Aug., the plants were moved outside to a container bed where they were grown under full sun and natural daylength. Daylength declined from $13 \mathrm{~h} 37 \mathrm{~min}$ on 1 Aug. to 11 h 55 min on 30 Sept. Typical maximum photosynthetic flux during August and September was 2000 and $1900 \mu \mathrm{mol} \cdot \mathrm{m}^{-2} \cdot \mathrm{s}^{-1}$, respectively. The average daytime highs during

Table 1. Effect of dikegulac applied at $0,2,4$, or 6 weeks after transplanting on flowering and size of 'Rainbow Gold' bougainvillea. Liners were transplanted to 4.5 -liter $(25.4-\mathrm{cm})$ baskets on 1 Aug.

\begin{tabular}{|c|c|c|c|c|c|}
\hline $\begin{array}{l}\text { Dikegulac } \\
\text { concn (ppm) }\end{array}$ & $\begin{array}{l}\text { Time of } \\
\text { application } \\
\text { (week) }\end{array}$ & $\begin{array}{l}\text { Time of } \\
\text { pruning } \\
\text { (weeks) }\end{array}$ & $\begin{array}{c}\text { Inflorescences/ } \\
\text { branch }^{2}\end{array}$ & $\begin{array}{l}\text { Width } \\
\text { (cm) }\end{array}$ & $\begin{array}{l}\text { Overall } \\
\text { quality }\end{array}$ \\
\hline 0 & $\ldots$ & 0,4 & $7.8 b^{x}$ & $64.8 \mathrm{~b}$ & $5.0 \mathrm{~b}$ \\
\hline 1200 & 0 & 0,4 & $4.4 \mathrm{~b}$ & $64.5 \mathrm{~b}$ & $3.0 \mathrm{c}$ \\
\hline 600 & 0 and 2 & 0,4 & $5.5 \mathrm{~b}$ & $72.9 \mathrm{ab}$ & $4.6 \mathrm{bc}$ \\
\hline 1200 & 4 & 0 & $17.2 \mathrm{a}$ & $72.8 \mathrm{ab}$ & $7.2 \mathrm{a}$ \\
\hline 600 & 4 and 6 & 0 & $19.2 \mathrm{a}$ & $83.7 \mathrm{a}$ & $5.0 \mathrm{~b}$ \\
\hline \multicolumn{6}{|c|}{ Application date, significance } \\
\hline 0 wk vs. 0,2 wk & & & NS & NS & NS \\
\hline 0 wk vs. 4 wk & & & ** & NS & *** \\
\hline 0,2 wk vs. 4,6 wk & & & ** & * & NS \\
\hline 4 wk vs. 4,6 wk & & & NS & * & $* *$ \\
\hline
\end{tabular}

yating scale was $1=$ poor to $10=$ excellent; values are means and represent the consensus of three

${ }^{x}$ Mean separation (within columns) by Duncan's multiple range test, $P=0.05$.

Ns,*,**,***Nonsignificant or significant at $P=0.05,0.01$, or 0.001 , tespectively. 
August and September were 34.9 and 32.2C, respectively, with average nighttime lows of 21.4 and $17.7 \mathrm{C}$, respectively.

All bougainvillea were tip-pruned ( 0.5 to $1 \mathrm{~cm}$ ) on 3 Aug. Plants were then sprayed with dikegulac at 600 or 1200 ppm (Atrimmec; PBI/Gordon, Kansas City, Kan.) at the time of pruning or 2, 4, or 6 weeks later. Bougainvillea not sprayed at 4 weeks were pinched; these plants also were pruned for shaping when it was necessary. The experiment was set up as a completely randomized design with six replications per treatment. Plants were hand-watered as needed, usually every 2 to 3 days.

On 3 Oct., height, width, the number of structural branches (branches longer than 15.2 $\mathrm{cm}$ ) with and without inflorescences, and the total number of inflorescences were recorded. The mean number of inflorescences per flowering structural branch was calculated. The overall aesthetic quality as a finished bougainvillea in the hanging baskets was rated on a scale where $1=$ poor and $10=$ excellent. Plants with an overall quality rating of 7 were considered marketable. Marketable plants were. defined as well branched with many fully expanded bracts, and at least $15 \mathrm{~cm}$ growth beyond the pot perimeter. The rating values recorded were our consensus. Data were subjected to analysis of variance by general linear model (GLM) procedures (SAS Institute, Inc., 1985). Means were separated using Duncan's multiple range test at $P=0.05$. Single-degree-of-freedom contrasts were conducted to determine the effect of timing of dikegulac treatment.

Marketable hanging baskets were produced 9 weeks after transplanting and pruning (WATP), but only when the bougainvillea were treated with $1200 \mathrm{ppm}$ dikegulac 4 WATP. Nine weeks is the average production time for this climate during the summer (Hatten's Nursery, personal communication). The number of inflorescences per branch and overall aesthetic quality were higher for a single $1200 \mathrm{ppm}$ dikegulac application 4 WATP than for the control (Table 1). Application of $600 \mathrm{ppm}$ dikegulac at 4 and 6 WATP similarly enhanced flowering, but the overall quality of these bougainvillea was lower than for one application of $1200 \mathrm{ppm}$ (Table 1), due to the proportion of bracts that had not yet fully expanded (no data collected). Therefore, dikegulac applied 4 WATP appeared to be the primary factor that promoted flowering during decreasing daylengths of late summer and early fall. Dikegulac at $1200 \mathrm{ppm}$ did not appear to reduce bract size, although 1600 ppm appeared to reduce 'Barbara Karst' bougainvillea bract size $\approx 25 \%$ to $50 \%$ as previously noted.

Height was unaffected by dikegulac (range 31.5-40.0 cm), but width tended to increase as time of application was delayed (Table 1). Bougainvillea treated with $600 \mathrm{ppm}$ dikegulac 0 and 2 WATP, then pruned 4 WATP, generally had more pendulous growth habits, an observation not shown in the quantitative data. However, bougainvillea not pruned 4 WATP occasionally had upright shoots that detracted from the overall aesthetic rating. Dikegulac had no effect on total number of structural branches per basket $(13.1 \pm 0.5)$.

In conclusion, marketable hanging baskets of 'Rainbow Gold' bougainvillea were produced from rooted liners in 9 weeks when treated with dikegulac under decreasing daylengths and high temperatures. However, one application of dikegulac did not reduce vegetative growth.

\section{Literature Cited}

Allard, A.H. 1935. Response of the woody plants Hibiscus syriacus, Malvaviscus conzatti. and Bougainvillea glabra to length of day. J. Agr. Res. 51:27-34.

Criley, R.A. 1977. Year around flowering of double bougainvillea: effect of daylength and growth retardants. J. Amer. Soc. Hort. Sci. 102:775778.

Dierking, C.M. and K.C. Sanderson. 1985. Effect of various chemical spray treatments on Bougainvillea spectabilis Wild. Proc. Southern Nurserymen's Assn. Res. Conf. 30:220-222.

Furuta, T., W.C. Jones, T. Mock, W. Humphrey, R. Maire, and J. Breece. 1972. Ancymidol applications retard plant growth of woody ornamentals. Calif. Agr. 26(3):10-12.

Hackett, W.P. and R.M. Sachs. 1966. Flowering in Bougainvillea 'San Diego Red'. Proc. Amer. Soc. Hort. Sci. 88:606-612.

Hackett, W.P. and R.M. Sachs. 1967. Chemical control of flowering in Bougainvillea 'San Diego Red'. Proc. Amer. Soc. Hort. Sci. 90:361-364.

Hatten's Nursery, Inc. 1990. 1990 catalog. Mobile, Ala.

Joiner, J.N., R.D. Dickey, and T.J. Sheehan. 1962. Growth and flowering of Bougainvillea glabra 'Sander' as affected by photoperiod and levels of nitrogen and potassium. Proc. Fla. State Hort. soc. 75:447-449.

SAS Institute, Inc. 1985. SAS/STAT guide for personal computers, version 6 edition. SAS Institute, Inc. Cary, N.C.

HoRTSCIENCE 27(1):36-39. 1992.

\title{
Calcium and Heat Treatments to Improve Storability of 'Anna' Apples
}

\author{
Susan Lurie ${ }^{1}$ and Joshua D. Klein ${ }^{2}$ \\ Agricultural Research Organization, The Volcani Center, Bet Dugan \\ 50250, Israel
}

Additional index words. Malus domestica, storage, cell walls

Abstract. Apples (Malus domestica Borkh. cv. Anna) were treated at harvest by a dip in $3 \% \mathrm{CaCI}_{2}$ solution, heated for 4 days at $38 \mathrm{C}$, or the two treatments combined, before being placed in OC storage. After removal of the apples from storage and holding them for 1 week at 20C, the combined treatment maintained fruit quality best. The fruit remained firmer than with either treatment separately, and peel yellowing and decreased titratable acidity caused by the heat treatment were less pronounced. Heat treatment alone maintained fruit firmness, while $\mathrm{CaCI}_{2}$ alone had no effect on fruit quality, although it raised the fruit calcium level more than the combined treatment in most experiments. Altering the temperature $(0,20$, or $38 \mathrm{C})$ of the $\mathrm{CaCl}_{2} \mathrm{dip}$ did not change its efficacy. There was less soluble and more insoluble pectin in cell wall extracts of apples from the combined treatment than from other treatments. In addition, proportionally less $\mathrm{Ca}$ was present in the water-soluble pectin fraction of the combined treatment compared to other treatments, indicating different binding properties in the cell wall.

'Anna' is an early summer apple that stores very poorly. It ripens very quickly after harvest and softens even during cold storage. However, it has very low cold requirements for growth and for that reason is the main apple variety grown in many subtropical countries. It would, therefore, be beneficial

Received for publication 31 Dec. 1990. This article is publication no. 3167-E, 1990 series, from the ARO, Bet Dagan, Israel. The research was funded in part by the United States-Israel Binational Agricultural Research and Development Foundation. The cost of publishing this paper was defrayed in part by the payment of page charges. Under postal regulations, this paper therefore must be hereby marked advertisement solely to indicate this fact.

'Dept. of Fruit and Vegetable Storage.

${ }^{2}$ Dept. of Field Crops. to enhance its storage properties and allow for a longer postharvest marketing period.

Calcium applications during the growing season or as postharvest dips are often used to enhance the storage life' of apples (Poovaiah, 1986. Calcium has long been associated with regulation of fruit ripening. Specifically, maintenance of relatively high calcium concentrations in fruit tissues results in slowing of ripening, as seen in lower respiration rates, reduced ethylene production, and slower softening of the fruit flesh. There are also some specific fruit disorders, such as bitter pit, that can be prevented if sufficient calcium is present (Ferguson, 1984). A postharvest heat treatment was also found to enhance the storeability of 'Anna' and 'Granny Smith' apples (Klein and Lurie, 1990). The rate of softening of fruit after 